\title{
Erratum to: Melt Strength and Rheological Properties of Biodegradable Poly(Lactic Acid) Modified via Alkyl Radical-Based Reactive Extrusion Processes
}

Katherine M. Dean · Eustathios Petinakis •

Sam Meure $\cdot$ Long Yu $\cdot$ Andrew Chryss

Published online: 5 September 2012

(C) Springer Science+Business Media, LLC 2012

Erratum to: J Polym Environ

DOI 10.1007/s10924-012-0461-2

Unfortunately, there is a typo in the original publication of the article title.

The correct version should be "Melt Strength and Rheological Properties of Biodegradable Poly(Lactic Acid) Modified via Alkyl Radical-Based Reactive Extrusion Processes".

The online version of the original article can be found under doi:10.1007/s10924-012-0461-2.

K. M. Dean $(\bowtie) \cdot$ E. Petinakis · S. Meure · L. Yu CSIRO Materials Science and Engineering,

Gate 5 Normanby Rd, Clayton 3168, Australia

e-mail: katherine.dean@csiro.au

A. Chryss

CSIRO Process Science and Engineering, Bayview Ave,

Clayton 3168, Australia 